\title{
Molecular characterization of siderophore biosynthesis in Paracoccidioides brasiliensis
}

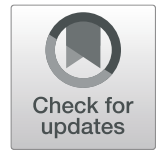

\author{
Marielle Garcia Silva ${ }^{1,2 \dagger}$, Juliana Santana de Curcio ${ }^{1 \dagger}$, Mirelle Garcia Silva-Bailão ${ }^{1}$, Raisa Melo Lima', \\ Mariana Vieira Tomazett ${ }^{1}$, Aparecido Ferreira de Souza ${ }^{1}$, Vanessa Rafaela Milhomem Cruz-Leite ${ }^{1}$, Nicolau Sbaraini ${ }^{3}$, \\ Alexandre Melo Bailão ${ }^{1}$, Fernando Rodrigues ${ }^{4,5}$, Maristela Pereira', Relber Aguiar Gonçales ${ }^{4,5}$ and \\ Célia Maria de Almeida Soares ${ }^{1 *}$ (D)
}

\begin{abstract}
Iron is an essential nutrient for all organisms. For pathogenic fungi, iron is essential for the success of infection. Thus, these organisms have developed high affinity iron uptake mechanisms to deal with metal deprivation imposed by the host. Siderophore production is one of the mechanisms that fungal pathogens employ for iron acquisition. Paracoccidioides spp. present orthologous genes encoding the enzymes necessary for the biosynthesis of hydroxamates, and plasma membrane proteins related to the transport of these molecules. All these genes are induced in iron deprivation. In addition, it has been observed that Paracoccidioides spp. are able to use siderophores to scavenge iron. Here we observed that addition of the xenosiderophore ferrioxamine B FOB) to $P$. brasiliensis culture medium results in repression (at RNA and protein levels) of the SidA, the first enzyme of the siderophore biosynthesis pathway. Furthermore, SidA activity was reduced in the presence of FOB, suggesting that P. brasiliensis blocks siderophores biosynthesis and can explore siderophores in the environment to scavenge iron. In order to support the importance of siderophores on Paracoccidioides sp. life and infection cycle, silenced mutants for the sidA gene were obtained by antisense RNA technology. The obtained AsSidA strains displayed decreased siderophore biosynthesis in iron deprivation conditions and reduced virulence to an invertebrate model.
\end{abstract}

Keywords: Iron, SidA, RNA interference

\section{INTRODUCTION}

Iron is an essential nutrient for growth and development of living organisms. Due to iron redox properties, this metal occurs in two oxidation states, ferrous ion $\left(\mathrm{Fe}^{+2}\right)$ and ferric ion $\left(\mathrm{Fe}^{+3}\right)$, which are influenced by $\mathrm{pH}$ and oxygen (Sanchez et al. 2017). $\mathrm{Fe}^{+2}$ spontaneously convert to $\mathrm{Fe}^{+3}$ in the presence of oxygen (Halliwell and Gutteridge 1984). Iron is indispensable for a variety of cellular processes such as respiration, although, the excess or incorrect storage of this metal by cells is harmful. The reduced form of iron $\left(\mathrm{Fe}^{+2}\right)$ catalyzes the production of reactive

\footnotetext{
* Correspondence: cmasoares@gmail.com

†Marielle Garcia Silva and Juliana Santana de Curcio contributed equally to this work.

'Laboratório de Biologia Molecular, Instituto de Ciências Biológicas, ICB II,

Campus II, Universidade Federal de Goiás, Goiânia, GO, Brazil

Full list of author information is available at the end of the article
}

oxygen species (ROS) through the Fenton/Haber Weiss reaction (Halliwell and Gutteridge 1984; Haber and Weiss 1934). In this way, the maintenance of the homeostasis of this micronutrient is essential. Proper iron homeostasis is achieved through fine-tuned regulation of iron acquisition, use and storage (Ganz 2009).

Nutritional immunity (i.e., host deprivation of metals, such $\mathrm{Fe}, \mathrm{Cu}, \mathrm{Mn}$ and $\mathrm{Zn}$ ) is an important mechanism employed by the host to control the development of pathogenic organisms, to overcome the low availability of iron imposed by the host, microorganisms developed high affinity mechanisms for iron uptake (Raymond et al. 2003). In fungal pathogens these mechanisms include: the reduction of $\mathrm{Fe}^{+3}$ to $\mathrm{Fe}^{+2}$, the acquisition of the iron bound to the heme group, and the solubilization of $\mathrm{Fe}^{+3}$ promoted by siderophores (Kornitzer 2009; Bailão et al.

(c) The Author(s). 2020 Open Access This article is licensed under a Creative Commons Attribution 4.0 International License, which permits use, sharing, adaptation, distribution and reproduction in any medium or format, as long as you give appropriate credit to the original author(s) and the source, provide a link to the Creative Commons licence, and indicate if changes were made. The images or other third party material in this article are included in the article's Creative Commons licence, unless indicated otherwise in a credit line to the material. If material is not included in the article's Creative Commons licence and your intended use is not permitted by statutory regulation or exceeds the permitted use, you will need to obtain permission directly from the copyright holder. To view a copy of this licence, visit http://creativecommons.org/licenses/by/4.0/. 
2012; Canessa and Larrondo 2013). The last strategy, also known as non-reductive iron uptake, is characterized by the use of siderophores, which are low molecular weight compounds that bind $\mathrm{Fe}^{+3}$ with high affinity making it available for consumption (Neilands 1993).

Fungal siderophore biosynthesis is well characterized in Aspergillus fumigatus (Blatzer et al. 2011; Schrettl et al. 2004; Schrettl et al. 2007) and internalization of the siderophore-iron complex is performed by Siderophore Iron Transporters (SIT), such as Sit, MirA, MirB and MirC, located on the cell surface, as described in Candida glabrata and Aspergillus nidulans (Nevitt and Thiele 2011; Haas 2003; Haas et al. 2003). Siderophores are also produced by fungi of the Paracoccidioides genus that cause paracoccidioidomycosis (PCM) (Restrepo 1985), a disease restricted to Latin America (San-Blas et al. 2002) with high rates in Brazil (Restrepo et al. 2001). Paracoccidioides spp. grow as mycelia in the environment and as yeast cells in host tissues (Restrepo 1985). After inhalation of conidia or mycelial propagules, these reach the pulmonary alveoli of the host and differentiate into yeast cells, thus initiating the infectious process (McEwen et al. 1987).

Fungi of the Paracoccidioides genus can use reductive $\left(\mathrm{Fe}^{+3}\right.$ to $\left.\mathrm{Fe}^{+2}\right)$ and siderophore uptake pathways to acquire iron under conditions of metal shortage (Silva et al. 2011; Silva-Bailao et al. 2014; Bailao et al. 2015). We have demonstrated that Paracoccidioides spp. present putative orthologue genes to those related to hydroxamate siderophore production ( $\operatorname{sid} A$, sidF, sidC, sidD, SidH and sidI) as well as siderophore uptake (sit1, mirB and mirC) (Silva et al. 2011; Silva-Bailao et al. 2014). All of them are up-regulated in iron restriction and, in such condition, hydroxamate siderophores are produced (Silva-Bailao et al. 2014, Parente et al. 2011). Furthermore, Paracoccidioides spp. can also explore siderophores from other organisms to scavenge iron, as dimerumic acid and ferrioxamine B (FOB). Additionally, prior exposure of $P$. brasiliensis to FOB increases fungus survival to phagocytosis by activated macrophages (Silva-Bailao et al. 2014).

Considering those findings, we sought to investigate the adaptation of $P$. brasiliensis after FOB exposure as well as the functional role of SidA, the first enzyme in the siderophore production, in this fungus. Moreover, knockdown strains for sidA were generated employing antisense RNA technology and Agrobacterium tumefaciens-mediated transformation (ATMT) (Almeida et al. 2007; Menino et al. 2012; Bailao et al. 2014). Notably, upon FOB exposure, P. brasiliensis' sidA was down regulated at transcriptional and translational levels, which was accompanied by reduced enzymatic activity. Furthermore, the knockdown of $\operatorname{sidA}($ AsSidA) led to reduced siderophore production by $P$. brasiliensis and decreased fungal virulence to Tenebrio molitor an invertebrate model, suggesting an essential role of siderophores in the infection cycle of $P$. brasiliensis.

\section{MATERIAL AND METHODS}

\section{Ethics statement}

Mouse manipulation was carried out in accordance with the ethical principles of animal research adopted by the Brazilian Society of Laboratory Animal Science and a Brazilian Federal Law 11.749 (October 2008). Male $\mathrm{BALB} / \mathrm{c}$ mice aged between 6 to 8 weeks were purchased from the Animal house of the Instituto de Patologia Tropical e Saúde Pública - UFG and were maintained in the Animal Facilities at the Laboratório de Biologia Molecular, Universidade Federal de Goiás. Animal experimentation was approved by institutional Ethics Commission on Animal Use of the Universidade Federal de Goiás - UFG (reference number 089/17).

\section{Strains and culture conditions}

Yeast cells of P. brasiliensis, Pb18 (ATCC32069) were used in all the experiments. Cells were maintained in brain heart infusion (BHI) solid medium added of $4 \%$ (w/v) glucose for 4 days, at $36^{\circ} \mathrm{C}$. For experiments, cells were grown in liquid $\mathrm{BHI}$ for $72 \mathrm{~h}$ at $36^{\circ} \mathrm{C}, 150 \mathrm{rpm}$, in order to reach the exponential growth phase $\left(10^{7}\right.$ cells per ml). Afterward, the cells were centrifuged at $1200 \mathrm{x}$ $g$ for $10 \mathrm{~min}$ at $4{ }^{\circ} \mathrm{C}$ and washed twice with Phosphate Buffered Saline (PBS) 1X. Cells were then incubated in McVeigh/Morton liquid medium (MMcM) (Restrepo and Jimenez 1980) containing: $4 \%(\mathrm{w} / \mathrm{v})$ glucose, $0.15 \%$ (w/v) $\mathrm{KH}_{2} \mathrm{PO}_{4}, 0.05 \%(\mathrm{w} / \mathrm{v}) \mathrm{MgSO}_{4} .7 \mathrm{H}_{2} \mathrm{O}, 0.015 \%(\mathrm{w} / \mathrm{v})$ $\mathrm{CaCl}_{2} .2 \mathrm{H}_{2} \mathrm{O}, 0.2 \% \quad(\mathrm{w} / \mathrm{v}) \quad\left(\mathrm{NH}_{4}\right)_{2} \mathrm{SO}_{4}, 0.2 \% \quad(\mathrm{w} / \mathrm{v}) \quad \mathrm{L}-$ asparagine, $0.02 \%(\mathrm{w} / \mathrm{v})$ L-cystine, $1 \%(\mathrm{v} / \mathrm{v})$ of vitamin supplement $(0.006 \%[\mathrm{w} / \mathrm{v}]$ thiamine, $0.006 \%[\mathrm{w} / \mathrm{v}]$ niacin B3, $0.006 \%[\mathrm{w} / \mathrm{v}] \mathrm{Ca}^{+2}$ pantothenate, $0.001 \%[\mathrm{w} / \mathrm{v}]$ inositol B7, $0.0001 \%[\mathrm{w} / \mathrm{v}$ ] biotin $\mathrm{B} 8,0.001 \%[\mathrm{w} / \mathrm{v}]$ riboflavin, $0.01 \%[\mathrm{w} / \mathrm{v}]$ folic acid B9, 0.01\% [w/v] choline chloride, $0.01 \%[\mathrm{w} / \mathrm{v}]$ pyridoxine) and $0.1 \%(\mathrm{v} / \mathrm{v})$ of trace elements supplement $\left(0.0057 \% \quad[\mathrm{w} / \mathrm{v}] \quad \mathrm{H}_{3} \mathrm{BO}_{3}, 0.0081 \% \quad[\mathrm{w} / \mathrm{v}]\right.$ $\mathrm{MnSO}_{4} .14 \mathrm{H}_{2} \mathrm{O}, 0.0036 \%[\mathrm{w} / \mathrm{v}] \quad\left(\mathrm{NH}_{4}\right)_{6} \mathrm{MO}_{7} \mathrm{O}_{24} \cdot 4 \mathrm{H}_{2} \mathrm{O}$, $0.0157 \%[\mathrm{w} / \mathrm{v}] \mathrm{CuSO}_{4} . \mathrm{H}_{2} \mathrm{O}, 0.1404 \%$ [w/v] $\mathrm{Fe}\left(\mathrm{NH}_{4}\right)_{2}(-$ $\left.\mathrm{SO}_{4}\right)_{2} .6 \mathrm{H}_{2} \mathrm{O}$ ) (Restrepo and Jimenez 1980) supplemented with $50 \mu \mathrm{M}$ of bathophenanthroline-disulfonic acid (BPS; Sigma-Aldrich, Germany), a ferrous iron-specific chelator, for $24 \mathrm{~h}$ at $36^{\circ} \mathrm{C}$ with shaking at $150 \mathrm{rpm}$ (Parente et al. 2011, Silva-Bailao et al. 2014). Cells were centrifuged and washed twice with PBS $1 \mathrm{X}$ and cell viability was determined using trypan blue. A total of $10^{7}$ cells per $\mathrm{mL}$ were transferred to $\mathrm{MMcM}$ medium containing $50 \mu \mathrm{M}$ of BPS or $10 \mu \mathrm{M}$ of ferrioxamine $\mathrm{B}$ with iron loaded (FOB; Sigma-Aldrich, Saint louis, USA) (SilvaBailao et al. 2014). Yeast cells were incubated at $36^{\circ} \mathrm{C}$ for 6 and 24h, $150 \mathrm{rpm}$. For culture in MMcM medium 
all the glassware was acid treated to remove residual traces of iron (Cox 1994).

\section{RNA extraction and quantitative real time PCR (RT-qPCR)}

Total RNA extraction was accomplished using TRIzol (TRI Reagent, Sigma-Aldrich, St. Louis, MO) and mechanical cell rupture (Mini-Beadbeater - Biospec Products Inc., Bartlesville, OK). The mRNA was reverse-transcribed using Super-Script III First-Strand Synthesis SuperMix (Invitrogen, Life Technologies). qRT-PCR was performed employing a QuantStudio5 real-time PCR system (Applied Biosystems Inc.) and SYBER green PCR master mix was used in the reaction mixture (Applied Biosystems, Foster City, CA). The sequences of forward and reverse oligonucleotides are listed in (Additional file 1: Table S1). The data were normalized with the $28 \mathrm{kDa}$ ribonucleoprotein (GenBank accession number XP_015701336). The relative expression levels of transcripts of interest were calculated using the standard curve method for relative quantification (Bookout et al. 2006).

\section{L-ornithine- $\mathrm{N}^{5}$-oxygenase enzymatic assay}

The enzymatic activity of L-ornithine- $\mathrm{N}^{5}$-oxygenase (SidA) was evaluated as previously described by Zhou et al. (1998) and Haas et al. (1999) with few modifications. Briefly, P. brasiliensis yeast cells were collected and suspended in $0.5 \mathrm{mM}$ potassium phosphate buffer ( $\mathrm{pH}$ 8.0). The suspension was transferred to tubes containing glass beads $(425-600 \mu \mathrm{m})$ and submitted to vigorous mixing in a bead beater apparatus (BioSpec) for 5 cycles with intervals of $30 \mathrm{~s}$ on ice. The samples were centrifuged $10,000 \times g$ for $15 \mathrm{~min}$ and the protein concentration in supernatants was determined with the (Bradford) reagent. To measure the enzymatic activity of SidA, equal amounts of proteins $(50 \mu \mathrm{g})$ of both conditions, yeast cells incubated with (BPS) or (FOB), were used. The reaction mixture containing $40 \mu \mathrm{l}$ of $0.5 \mathrm{mM}$ potassium phosphate $\mathrm{pH} 8.0,10 \mu \mathrm{l}$ of $10 \mathrm{mM} \mathrm{NADPH}$, $2 \mu \mathrm{l}$ of $0.5 \mathrm{mM}$ FAD, $50 \mu \mathrm{g}$ of cell extract, $30 \mu \mathrm{l}$ of 10 mML-ornithine was incubated at $30{ }^{\circ} \mathrm{C}$ for $2 \mathrm{~h}$ and added of $100 \mu \mathrm{l}$ of $0.2 \mathrm{M}$ perchloric acid to stop the reaction. For control, the same amount of perchloric acid was added to one sample before incubation. The samples were centrifuged and the supernatants were used to determine the absorbance at $340 \mathrm{~nm}$.

\section{Molecular modeling of SidA}

The amino acid sequence of the $P$. brasiliensis SidA (PADG_00097) was modeled with ITASSER algorithm (Yang and Zhang 2015) available at (https://zhanglab. ccmb.med.umich.edu/). To predict protonation states of the model, the PDB2PQR server (http://nbcr-222.ucsd. edu/pdb2pqr_2.0.0/) at pH 7 was used. Pymol visualizer was used to perform the structural analysis (Rigsby and Parker 2016).

The MD simulation was performed by the GROMACS 4.5.5 package, using the AMBER force field (ff99SB-ILDM) in the presence of water TIP3P. The protein was subjected to the simulation of $100 \mathrm{~ns}$, temperature of $300 \mathrm{~K}$, pressure of $1 \mathrm{~atm}$ and time interval of 2 fentoseconds, without restriction of the conformation (Pronk et al. 2013).

Analysis of Clusters, Root Mean Square Deviation (RMSD) and Root Mean Square Fluctuations (RMSF) were performed using the software of the GROMACS package. The quality analysis and the Ramachandran diagram of the final MD model were performed using the MolProbity server (http://molprobity.biochem.duke. edu/) (Chen et al. 2010).

\section{Heterologous expression of recombinant SidA}

Primers used for amplification of SidA cDNA were listed in (Additional file 1: Table S1). The PCR product was sub cloned into the BamHI/EcoRI sites of pGEX-4 T3 vector (GE Healthcare Life Sciences). Transformation of Escherichia coli Rosetta (DE3) was carried out using standard procedures. For protein expression, transformed cells were cultured in LB medium supplemented with ampicillin $(100 \mu \mathrm{g} / \mathrm{ml})$ for $16 \mathrm{~h}$ at $37^{\circ} \mathrm{C}$. The induction of the recombinant protein was performed by addition of Isopropyl $\beta$ D-1-thiogalactopyranoside (IPTG; Sigma-Aldrich, St Louis, MO, USA) at a final concentration of $1 \mathrm{mM}$ for $2 \mathrm{~h}$. The size and identity of the recombinant protein SidA (rSidA) was evaluated using SDS-PAGE and in-gel protein digestion (Rezende et al. 2011) followed by LC-MS/MS (Lima Pde et al. 2015).

\section{Polyclonal antibodies production and immunoblotting assay}

rSidA was used in the production of specific mouse polyclonal antibodies. Pre-immune sera were obtained and stored at $-20^{\circ} \mathrm{C}$. The rSidA was extracted from the SDS-PAGE polyacrylamide gel, and subsequently injected into mouse three times at 15 days intervals. The obtained sera were sampled and stored at $-20{ }^{\circ} \mathrm{C}$.

A total of $40 \mu \mathrm{g}$ of the protein extract was loaded on $12 \%$ SDS-PAGE, stained with (Coomassie Blue R) or transferred to Hybond ECL membrane (GE Healthcare) as described by Lima and colleagues (Lima Pde et al. 2015). Blocked membranes were incubated with anti-SidA polyclonal antibodies diluted 1:150 for $2 \mathrm{~h}$. After incubation, the membrane was washed and incubated with anti-mouse secondary antibody alkaline phosphatase conjugated (1: 20000). The reaction was developed using 5-bromo-4chloro-3-indolylphosphate/nitroblue tetrazolium (BCIP/ NBT). As a load control was employed anti-enolase polyclonal antibodies (Nogueira et al. 2010). The pixel intensity 
of the bands was analyzed using the Image 1.51 software (Schneider et al. 2012) and expressed as arbitrary units.

\section{Extraction and digestion of proteins for nano-ESI-UPLC- $\mathrm{MS}^{\mathrm{E}}$ acquisition}

Protein extraction was performed by protocol described by Baeza and coleagues (Baeza et al. 2017). The protein concentration in the supernatant was determined using the Bradford reagent (Bradford 1976). Bovine serum albumin was used as a standard. Integrity of the proteins was verified using a $12 \%$ SDS-PAGE. A total of $150 \mu \mathrm{g}$ of cytoplasmic protein was prepared for nanoUPLC-MS ${ }^{\mathrm{E}}$ analysis, as previously described (Lima Pde et al. 2015; Murad et al. 2011). After digestion, the peptides were ressuspended in $30 \mu \mathrm{l}$ of ultrapure water and subsequently purified in ZipTip C18 Pipette Tips (Millipore, MA, USA) and dried in a speed vacuum. The obtained peptides were suspended in $80 \mu \mathrm{l}$ of a solution containing $20 \mathrm{mM}$ of ammonium formiate and $200 \mathrm{fmol} / \mu \mathrm{L}$ of PHB (MassPREP ${ }^{\mathrm{mm}}$ protein). After solubilization, peptides were transferred to a Waters Total Recovery vial (Waters Corporation, MA, USA). For separation of tryptic peptides, Nanoscale LC was performed using an ACQUITY UPLC ${ }^{\bullet}$ M-Class system (Waters Corporation, MA, USA) (Tomazett et al. 2019).

\section{Data processing and protein identification}

Data processing were performed as previously described (Lima Pde et al. 2015). In brief, for proteomic analyzes of the data obtained from the LC-MS ${ }^{\mathrm{E}}$, the ProteinLynx Global Server version 3.0.2 (Waters, Manchester, UK) was employed. The processed spectra were searched against $P$. brasiliensis ( $P b 18)$ protein sequences (https://www.uniprot.org/proteomes/). The protein identification criteria also included the detection of at least 2 fragment ions per peptide, 5 fragments per protein and the determination of at least 1 peptide per protein. A protein that showed a variance coefficient of 0.057 and that was detected in all replicates was used to normalize the protein expression levels in the samples (PADG_04570). Expres$\operatorname{sion}^{\mathrm{E}}$ informatics v.3.0.2 was used for quantitative comparisons. The mathematical model used to calculate the ratios was part of the Expression ${ }^{\mathrm{E}}$ algorithm inside the PLGS software from the Waters Corporation (Geromanos et al. 2009). The minimum repeat rate for each protein in all replicates was 2. Protein tables generated by ProteinLynx Global Server were merged, and the dynamic range of the experiment was calculated using the software program MassPivot v1.0.1. The data obtained by NanoUPLC-MS ${ }^{\mathrm{E}}$ were subjected to in silico analysis to identify functional classification. For this analysis, it was used FungiDBdatabase (https://fungidb.org/fungidb/).

\section{Construction and characterization of the $P$. brasiliensis SidA antisense-RNA strain}

The functional evaluation of SidA was performed by antisense RNA technique, as described by Bailão and colleagues (Bailao et al. 2014) and Parente-Rocha et al. (2015). A tumefaciens strain LBA 1100 was used for $P$. brasiliensis genetic transformation experiments. The cells from A. tumefaciens were cultured in induction medium (IM) for co-cultivation. Transformants were selected in BHI medium containing hygromycin $75 \mu \mathrm{g} / \mathrm{mL}$ $(\mathrm{w} / \mathrm{v})$ and randomly selected clones were confirmed for silencing by qRT- PCR. RNA extraction, cDNA synthesis and real-time PCR procedure were performed.

P. brasiliensis wild type (WT), empty vector (EV) and silenced for sidA gene (AsSidA) were cultured in liquid $\mathrm{MMcM}$ at $36^{\circ} \mathrm{C}$ and $180 \mathrm{rpm}$ in the presence of iron. Cell growth was evaluated by optical density at a wavelength of $600 \mathrm{~nm}$ every $24 \mathrm{~h}$. Cell viability analysis was evaluated by staining with $1 \mu \mathrm{g} / \mathrm{mL}$ (wt/vol) propidium iodide (Sigma Aldrich). The samples were analyzed in a fluorescence microscope (Zeiss Axiocam MRc - Scope A1) (Zambuzzi-Carvalho et al. 2013).

Siderophore production assayed by chrome azurol (CAS) Siderophore production was analyzed as described previously (Silva-Bailao et al. 2014). For the overlay CAS (OCAS) assay, $10^{6}$ yeast cells were grown in solid MMcM medium with no iron supplementation for 5 days. After that, $15 \mathrm{ml}$ of CAS solution (Schwyn and Neilands 1987) were applied over the plates. The ternary complex Chrome Azurol $\mathrm{S} / \mathrm{Fe}^{3+} /$ hexadecyltrimetyl ammonium bromide (HDTMA) acts as an indicator of siderophore production, since it is originally blue and turns orange in presence of siderophores (Perez-Miranda et al. 2007).

The percentage of siderophores production was also determined (Machuca and Milagres 2003). Briefly, $10^{6}$ yeast cells were grown in MMcM liquid medium with no iron supplementation or with different concentrations of ammonium ferrous sulfate $(2.5 \mu \mathrm{m}, 5 \mu \mathrm{m}, 10 \mu \mathrm{m}$ and $30 \mu \mathrm{m})$. After 5 days of growth, the culture supernatants were collected by centrifugation at 10,000 $\mathrm{x} g$ for 1 min and $400 \mu \mathrm{l}$ were incubated with the same volume of CAS liquid medium (Schwyn and Neilands 1987). The reference sample was prepared by adding $400 \mu \mathrm{L}$ of sterile MMcM without iron or with different iron concentrations to $400 \mu \mathrm{L}$ of CAS liquid medium. After $1 \mathrm{~h}$ of incubation at room temperature in the dark, the absorbance at $630 \mathrm{~nm}$ (Ultraspec $2000 \mathrm{UV} /$ Visible Spectrophotometer Pharmacia Biotech) was determined. The percentage of siderophore activity was calculated by subtracting the sample absorbance values from the reference according to the following formula $[(\mathrm{Ar}-\mathrm{As} / \mathrm{Ar})] \times$ 100, in which Ar means absorbance of reference and As absorbance of sample. 


\section{Standardization of Tenebrio molitor larvae as an infection model for $P$. brasiliensis}

T. molitor larvae were acquired from a local supplier and maintained in oatmeal diet until experimentation. $P$. brasiliensis yeast cells were cultured in BHI as previously described, collected through centrifugation, washed three times with PBS $1 \mathrm{X}$ and resuspended in PBS. The cells were repeatedly passed through a 18-gauge needle coupled to a $5 \mathrm{~mL}$ syringe and later strained through a $40 \mu \mathrm{m}$ nylon filter to obtain a homogenous cell suspension. The cells were counted with a hemocytometer and diluted to specific concentrations with PBS. Hemocoel injection was performed with a Hamilton syringe (Sigma-Aldrich) in T. molitor larvae weighing between 150 and 200 $\mathrm{mg}$, showing light and uniform color and absence of pigmented spots. The infection was performed in the ventral part of the larva, in the second segment after the paws and the volume of cell suspension was $5 \mu \mathrm{L}$ (e.g., harboring $1 \times 10^{5}, 1 \times 10^{6}$ or $2 \times 10^{6}$ cells). The larvae were kept in Petri dishes at $37^{\circ} \mathrm{C}$. The number of dead larvae was evaluated every $24 \mathrm{~h}$ for 10 days and deceased larvae were removed from the plate. As a control, the larvae were inoculated under the same conditions described above with PBS 1X. The experiments were performed with a total of 30 larvae per group.

\section{Evaluation of AsSidA virulence in $T$. molitor larvae}

P. brasiliensis yeast cells of WT, EV and AsSidA mutants were cultured and prepared as previously described. The infection was performed as previously described, employing $2 \times 10^{6}$ cells. The larvae were kept in Petri plates at $37^{\circ} \mathrm{C}$ and the amount of dead larvae was evaluated every $24 \mathrm{~h}$ for 10 days. As a control, the larvae were inoculated under the same conditions described above with PBS 1X. The experiments were performed with a total of 30 larvae per group.

\section{Statistical analysis}

Student's $t$-test was used for the statistical analysis of the following experiments, enzymatic activity, qRT-PCR, immunobloting analysis and siderophores production. The following $P$ values: $p \leq 0.0005, p \leq 0.005$ and $p \leq 0.05$ were considered statistically significant, for each cited experiments, respectively. For the experiments in T. molitor the GraphPad Prism 5 program was used to generate the survival curve (using the Kaplan - Meier method) and for statistical analysis (Logrank [Mantel-Cox]). $p$ value $<0.05$ was considered significant (de Souza et al. 2015; de Souza et al. 2018a, 2018b).

\section{RESULTS}

Molecular modeling of SidA demonstrates its interaction with substrates for the first step in siderophore biosynthesis

Although P. brasiliensis has orthologs for the all the components for siderophore biosynthesis, the functionality of this pathway still remains elusive. Therefore, we employ molecular modeling to describe in silico the structural characteristics of SidA and its possible ligands. The described SidA proteins harbor a conserved domain of the superfamily of oxygenases (Pfam 13,434; This domain is conserved in the putative SidA of $P$. brasiliensis) and require NADPH and FAD as cofactors. The crystallized protein with the most similar three-dimensional structure corresponds to A. fumigatus SidA, with $47 \%$ identity (PDBID: 4B63) (Franceschini et al. 2012; Krithika et al. 2006). Thus, molecular modeling of $P$. brasiliensis putative SidA was employed, in order to support and identify amino acid residues that hypothetically bind to FAD, NADPH and L-ornithine. The molecular modeling and three-dimensional structure comparison was based on A. fumigatus SidA (i.e, already crystallized protein; PDBID: 4B63) displaying 47\% identity with $P$. brasiliensis putative SidA ortholog.

The (Additional file 2: Fig. S1 A) shows the alignment of $A$. fumigatus SidA (gray) and $P$. brasiliensis SidA (blue) showing a preserved site of interaction with L-ornithine, FAD and $\mathrm{NADPH}$. The amino acid residues that interact with Lornithine in A. fumigatus are LYS107, ASN323 and SER469, which in the $P$. brasiliensis model correspond to LYS88, ASN306 and SER448, respectively (Additional file 2: Fig. S1 B). The interaction between NADPH and FAD occurs through a triad of amino acids GLN102, VAL168 and ARG279 in the crystal of A. fumigatus, corresponding to GLN83, VAL149 and LYS262 in P. brasiliensis (Additional file 2: Fig. S1 C).

P. brasiliensis SidA was subjected to molecular dynamics (MD) simulation and the Clusters and RMSD analyzes showed that the equilibration phase started in 20 ns and stabilized in approximately $60 \mathrm{~ns}$ (Additional file 3 : Fig. S2 A and B). Cluster 1 was the most relevant, as it remained between $20 \mathrm{~ns}$ until the end of the simulation, with no significant differences between the conformational models during this simulation period.

The quality parameters generated through clashscore and MolProbity showed high values for the model prior to MD 12.28 and 3.18, respectively. After the MD, the values were 0 and 1.28, respectively, showing a significant improvement in the quality of the structure, mainly considering the reduction of shocks between the atoms (Additional file 4: Table S2). In the Ramachandran diagrams (Additional file 3: Fig. S2 C and D) we observed a decrease in amino acid residues in non-permitted regions (according to the $p h i$ and $p s i$ angles).

The most flexible regions of $P$. brasiliensis SidA, according to the RMSF analysis, and the SidA pockets are shown (Additional file 3: Fig. S2 E and F). It is worth mentioning that the unstable regions highlighted in the RMSF do not correspond to the regions of the catalytic site. As the structural analyzes showed a high-quality for P. brasiliensis SidA model, this structure could be used for other structure-based approaches. Thus, the analysis 
of the molecular structure, suggests that SidA binds to L-ornithine as a substrate, and this reaction depends on $\mathrm{NADPH}$ and FAD.

\section{Expression and enzyme activity of SidA upon FOB exposure}

Once the functionally of $P$. brasiliensis SidA was supported through molecular modelling, the effects of FOB treatment over $P$. brasiliensis was thorough examined. The transcript levels of $\operatorname{sid} A$ were evaluated in the presence of FOB. Notably, sidA transcripts were down regulated at 6 and $24 \mathrm{~h}$ in FOB condition when compared to to iron starvation condition (BPS) (Fig. 1a). Additionally, the enzymatic activity of SidA decreased in P. brasiliensis yeast cells grown in the presence of FOB (iron loaded siderophore) (Fig. 1b), poiting for a correlation between transcript levels and enzyme amount. The data strongly suggested that the presence of an exogenous siderophore represses the biosynthesis of endogenous siderophores, since the fungus can be using $\mathrm{Fe}^{3+}$ attached to the xenosiderophore as an alternative iron source.

\section{SidA recombinant protein and polyclonal antibodies} production allows the identification of SidA in yeast cells The levels of SidA in P. brasiliensis cells were evaluated by western blotting with antibodies raised against recombinant SidA (rSidA). P. brasiliensis SidA protein was expressed in E. coli Rosetta (DE3) and rendered a protein with molecular mass of $79.5 \mathrm{kDa}$, corresponding to $53.5 \mathrm{kDa}$ of SidA fused to $26 \mathrm{kDa}$ of GST-tag (Fig. 2a). Following induction with IPTG, polyacrylamide gel pieces containing the recombinant protein were subjected to in-gel protein digestion for identification by LC-MS/MS approach; that confirmed the recombinant protein as SidA (Additional file 5: Fig. S3 and Additional file 6: Table S3). Immunoblotting results showed a decreased level of SidA in FOB-treated yeast cells when compared to BPS (Fig. 2b), corroborating the results obtained at transcript level. For loading control, membranes containing the same samples as in B were incubated with anti-Pbenolase polyclonal antibodies (Fig. 2c).

\section{Label free proteomic analysis reveals that SidA is} repressed in yeast cells grown in the presence of $F O B$

Proteomic analysis of $P$. brasiliensis yeast cells in presence of FOB and BPS was performed to evaluate alterations in the protein profile between both conditions. It was identified 431 and 475 proteins in BPS or FOB, respectively, in both time points, of 6 and $24 \mathrm{~h}$ (data not shown). Table 1 features the identified proteins, related to the synthesis of siderophores, which include those down and non-regulated. Proteins such as arginase (PADG_00637), ornithine aminotransferase (PADG_01328), glutamate-5-semialdehyde dehydrogenase (PADG_05337), NADP-specific glutamate dehydrogenase (PADG_04516), arginosuccinate synthase (PADG_00888), hydroxymethylglutarylCoA lyase (PADG_07031) and acetyl-CoA acetyltransferase (PADG_2751), which are related to the synthesis of ornithine, arginine and acetyl-CoA, respectively, were identified in the proteome. Notably, only SidA was down regulated after $24 \mathrm{~h}$ of incubation with FOB (Fig. 3 and Table 1).

\section{Characterization of sidA silenced strains}

The data obtained from gene expression, enzymatic activity, proteome and molecular modeling of SidA point to the function of this protein in P. brasiliensis as an

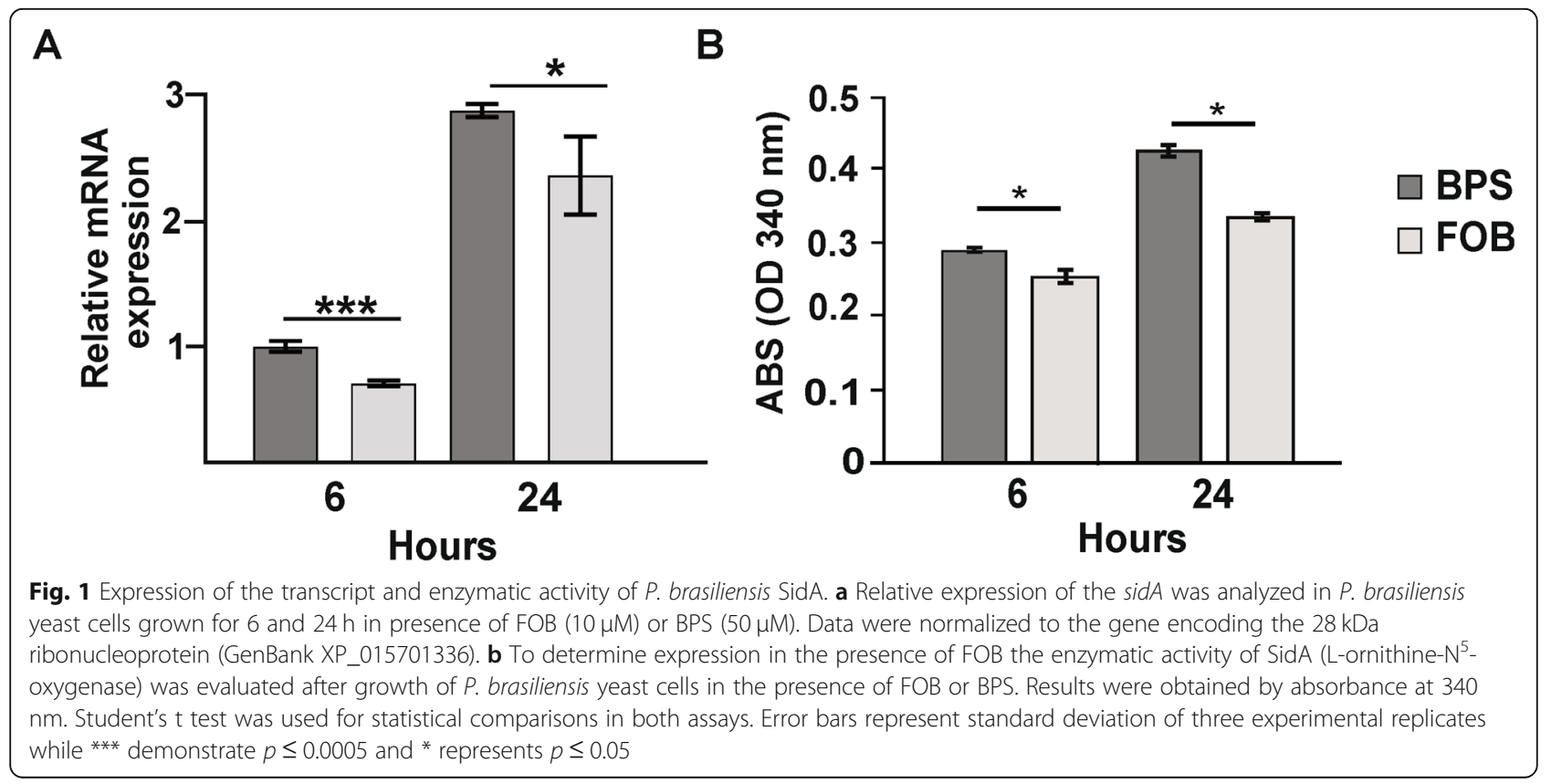




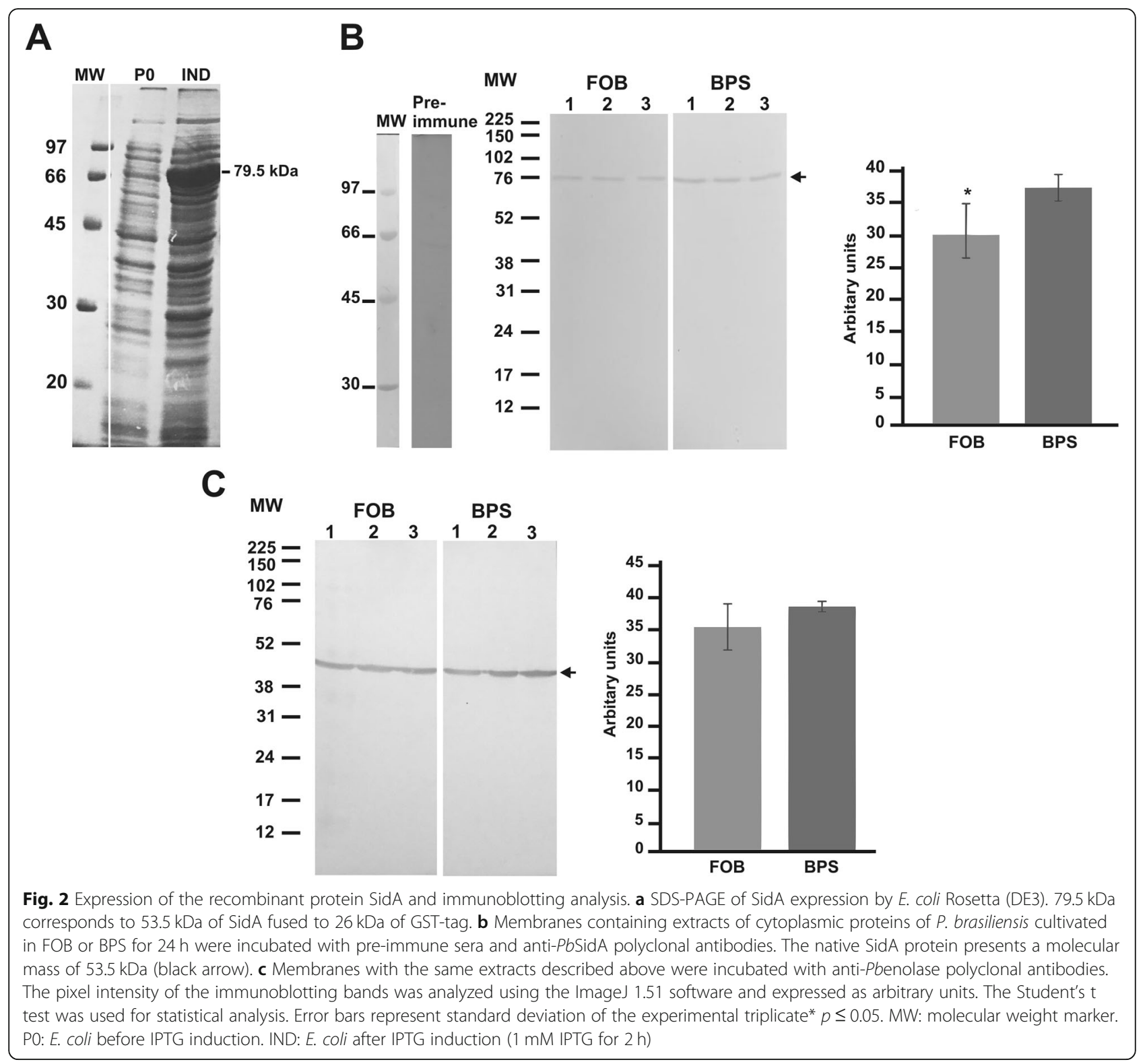

enzyme directly involved with the production of siderophores. Therefore, knockdown strains were constructed to determine the SidA role in P. brasiliensis. For that, it was used the antisense RNA technology, Fig. 4a depicts the sidA knockdown T-DNA cassette. This methodological approach provided sidA-knocked-down strains in $P$. brasiliensis yeast cells as demonstrated by qRT-PCR (Fig. 4b). The silencing percentage of six randomly selected clones ranged from 78 to $91 \%$ compared to those transformed with empty vector. AsSidA mutants grow similarly to the wild type and empty vector clones in MMcM medium supplemented with iron until $192 \mathrm{~h}$. In addition, cells remained viable during the entire time growth (Fig. 4c).

\section{sidA silenced strains present reduced siderophore production}

Silenced clones were subjected to iron deprivation and subsequently subjected to O-CAS assay. As expected, in iron scarcity, WT and EV strains are still able to produce siderophores, while theknockdown strains (AsSidA4 and AsSidA5) displayed a reduced production of these compounds (Fig. 5a). Furthermore, the siderophore production was evaluated in WT and AsSidA5 strains after 5 days of growth in iron deprivation and in different iron concentrations (Fig. 5b). There was a pronounced decrease in siderophores production in AsSidA5 strain in presence and absence of iron. 
Table 1 Proteins related to the biosynthesis of siderophores identified in proteomic analysis

\begin{tabular}{|c|c|c|c|}
\hline Accession number ${ }^{\mathbf{a}}$ & Description $^{\mathbf{b}}$ & Time Point $^{\mathbf{c}}$ & Score $^{\mathbf{d}}$ \\
\hline PADG_00637 & Arginase (325 aa) & $6 \mathrm{~h}$ & 1131.29 \\
\hline PADG_00637 & Arginase (325 aa) & $24 \mathrm{~h}$ & 1171.88 \\
\hline PADG_01328 & Ornithine aminotransferase (461 aa) & $6 \mathrm{~h}$ & 2299.86 \\
\hline PADG_01328 & Ornithine aminotransferase (461 aa) & $24 \mathrm{~h}$ & 1175.4 \\
\hline PADG_00888 & Argininosuccinate synthase (416 aa) & $6 \mathrm{~h}$ & 3507.13 \\
\hline PADG_00888 & Argininosuccinate synthase (416 aa) & $24 \mathrm{~h}$ & 4840.6 \\
\hline PADG_07031 & Hydroxymethylglutaryl-CoA lyase (357 aa) & $6 \mathrm{~h}$ & 2406.52 \\
\hline PADG_07031 & Hydroxymethylglutaryl-CoA lyase (357 aa) & $24 \mathrm{~h}$ & 2627.2 \\
\hline PADG_05337 & Glutamate-5-semialdehyde dehydrogenase (457 aа) & $6 \mathrm{~h}$ & 1209.7 \\
\hline PADG_05337 & Glutamate-5-semialdehyde dehydrogenase (457 aа) & $24 \mathrm{~h}$ & 771.05 \\
\hline PADG_04516 & NADP-specific glutamate dehydrogenase (460 aa) & $24 \mathrm{~h}$ & 501.85 \\
\hline PADG_02751 & Acetyl-CoA acetyltransferase (400 aa) & $6 \mathrm{~h}$ & 4328.06 \\
\hline PADG_02751 & Acetyl-CoA acetyltransferase (400 aa) & $24 \mathrm{~h}$ & 3019.16 \\
\hline PADG_00097 & L-ornithine- $\mathrm{N}^{5}$-monooxigenase $(475 \mathrm{aa})^{\mathrm{e}}$ & $24 \mathrm{~h}$ & 360.99 \\
\hline
\end{tabular}

$\overline{\mathrm{a}, \mathrm{b}}$ Accession number and description of protein according to database of Paracoccidioides spp.(http://www.uniprot.proteomes/)

c Time of treatment with FOB

${ }^{d}$ Protein score obtained from MS data using the PLGS

e Regulated Protein

SidA can be a putative virulence factor in $P$. brasiliensis

Since it was the first virulence study of the effects of $P$. brasiliensis over $T$. molitor through intra-hemocoel injection, it was necessary to standardize the amount of cells needed to accomplish a successful infection in the larvae. First, only yeast cells of WT strain were employed to perform the standardization, followed by mutant analysis (EV and AsSidA strains). Thus, different concentrations of $P$. brasiliensis cells $\left(1 \times 10^{5}, 1 \times 10^{6}\right.$ or $\left.2 \times 10^{6}\right)$ were inoculated in $T$. molitor larvae. As expected, larvae inoculated with $P$. brasiliensis cells showed an increase in the mortality rate as the fungus concentration also increased. The concentrations of $1 \times 10^{5}$ cells was not enough to kill all T. molitor larvae, which showed a survival rate of $75 \%$ after 10 days of infection. Furthermore, $1 \times 10^{6}$ cells of $P$. brasiliensis were not able to kill all larvae, presenting a survival rate of $57 \%$ after 10 days. In light of these results, an ideal concentration of $2 \times 10^{6}$ cells was chosen. This concentration led to $100 \%$ mortality after 7 days post infection (Fig. 6a).

Once the ideal cell concentration was established, the ability of the AsSidA strains (AsSidA4 and AsSidA5) to kill the $T$. molitor larvae was evaluated, comparing with WT and EV strains (Fig. 6b). Larvae infected with EV had a survival rate of only $4 \%$ after 10 days of infection, while larvae infected with AsSidA mutant strains had a

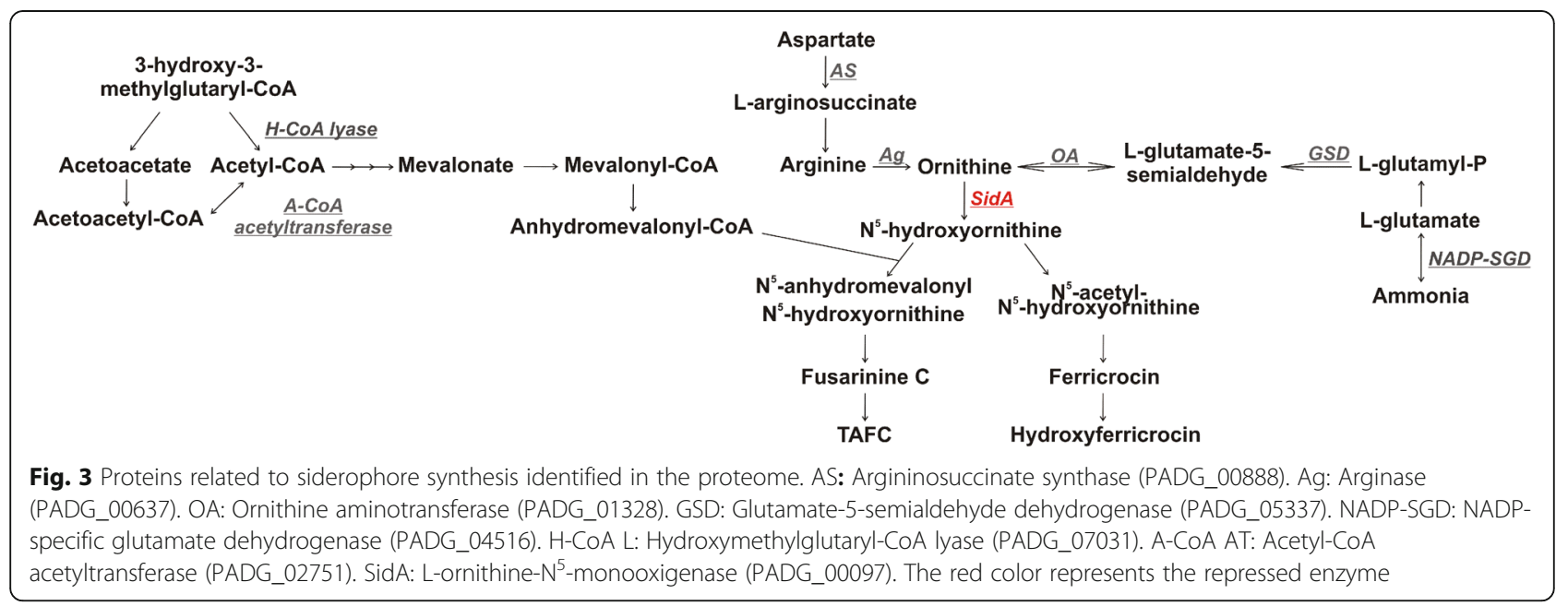




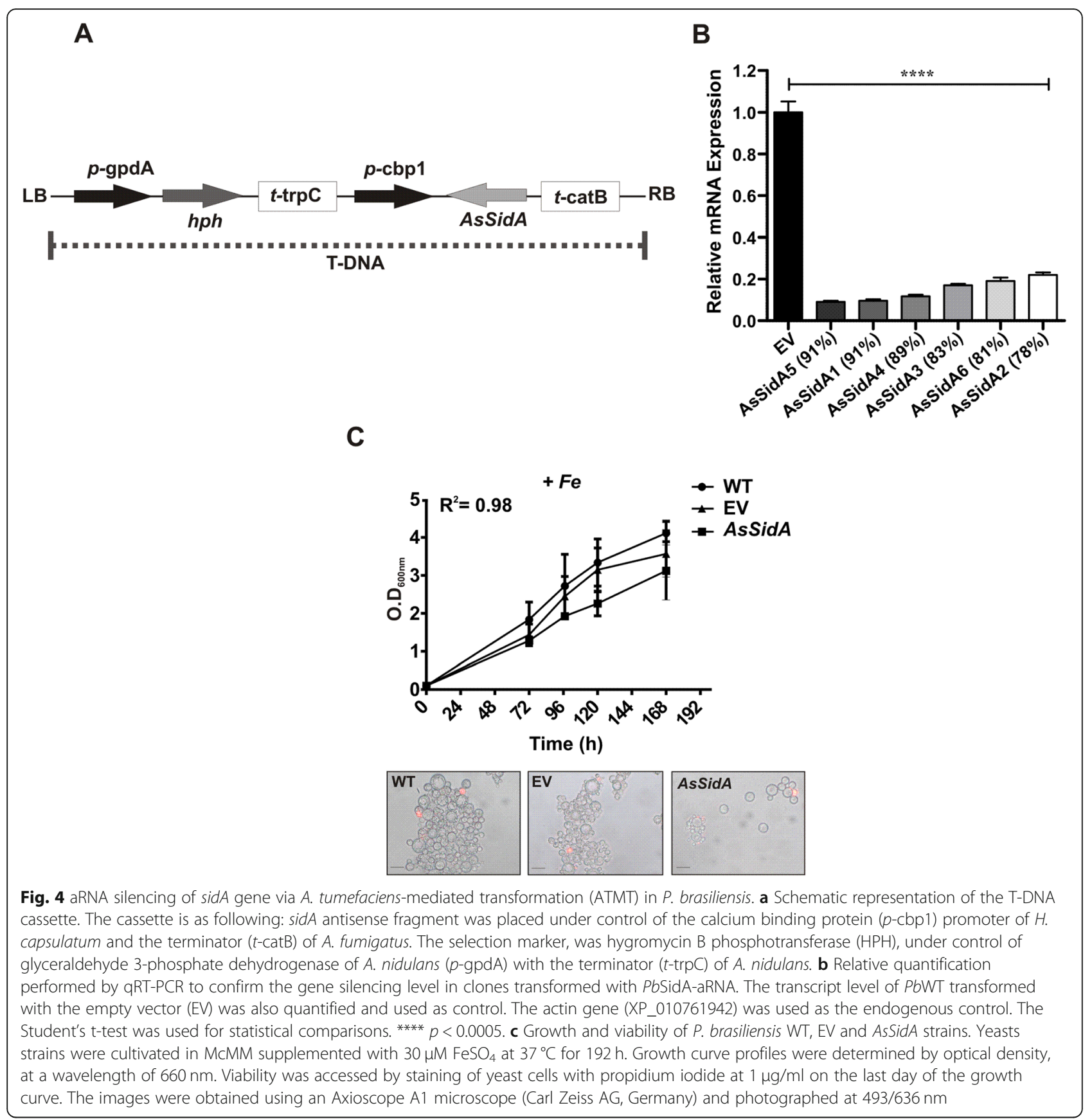

statistically significant reduction in larvae mortality, with a survival rate of 16 and $18 \%$, respectively. These results point that the silencing of SidA affects the pathogenesis of $P$. brasiliensis, further supporting the role of siderophores on Paracoccidioides infection process.

\section{DISCUSSION}

SidA is an enzyme specific for hydroxylation of ornithine, a precursor molecule of ferricrome siderophores biosynthesis (Chocklett and Sobrado 2010). The three-dimensional structure of SidA in A. fumigatus demonstrates the presence of amino acid residues essential for both NAPDH association and ornithine binding and hydroxylation (Robinson et al. 2015; Robinson et al. 2014). In this sense, SidA structure from $P$. brasiliensis was studied since the capacity of ornithine hydroxylation and use of NADPH as cofactor are specific to this enzyme (Chocklett and Sobrado 2010), which are influenced by the amino acids present in its structure (Robinson et al. 2014; Robinson et al. 2015). The characterization of the three-dimensional SidA structure of $P$. brasiliensis was performed by molecular modeling based on A. fumigatus crystal, which is most similar structure available (Sanchez 
A

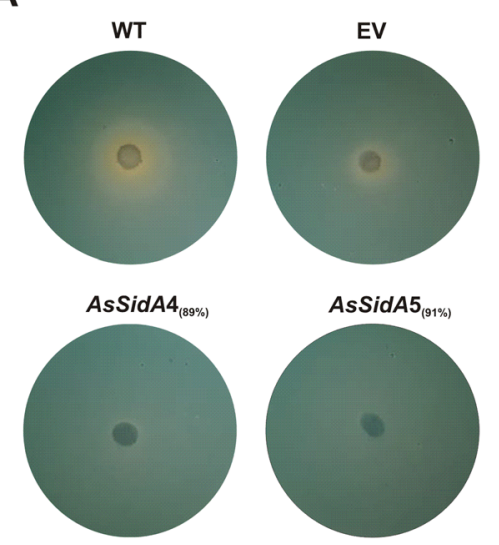

B

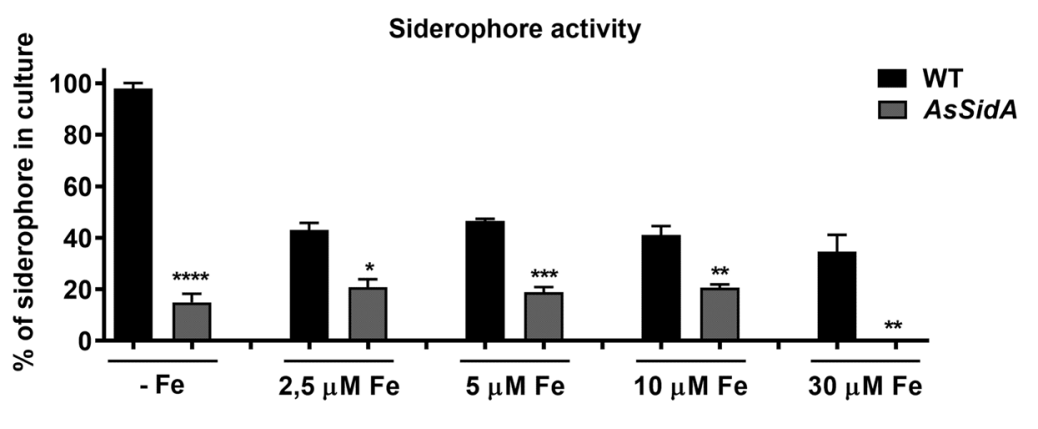

Fig. 5 Production of siderophores in sidA silenced strains. a Wild type (WT), empty vector (EV) and silenced sidA (AsSid4 and AsSid5) strains were grown in iron limited MMCM for 5 days. Following, the O-CAS plate assay was performed. The presence of secreted siderophores induces the formation of an orange halo. $\mathbf{b}$ After 5 days of growth in iron limited MMcM liquid medium or in MMcM added of different concentrations of inorganic iron, the percentage of siderophores produced by different strains was verified by the CAS liquid assay. Control of the reaction was performed by incubating the culture medium with CAS without fungal cells. The presence of siderophores was compared spectrophotometrically with the values obtained in the control by the values obtained from the supernatant of the different cultures. The results were presented in percentage. Statistical analysis was performed by Student's t test. Error bars represent standard deviation of three experimental replicates while ${ }^{* * *}$ demonstrates $p \leq 0.0005,{ }^{* *} p \leq 0.005$ and ${ }^{*} p \leq 0.05$

et al. 2017). The amino acids from the active site ASN, SER and LYS coordinate L-ornithine in the pocket so that it can interact with NADPH and FAD. In A. fumigatus, mutations targeting residues in the L-ornithine binding site altered the substrate coupling and the kinetic parameters of the reaction. Among all mutations analyzed, alterations in LYS107, which corresponds to LYS88 in P. brasiliensis, led to important changes in the enzymatic kinetics and, therefore, it was considered the most important amino acid involved in enzymatic kinetics (Kosman 2003). Thus, molecular structure data confirm that the active site of $P$. brasiliensis SidA is conserved and has similar interaction residues when compared to A. fumigatus SidA.
We have previously demonstrated that members of the Paracoccidioides complex can use the heterologous siderophore ferrioxamine B (FOB) as an iron source and produce siderophores when grown in iron starvation conditions (Silva-Bailao et al. 2014). In an attempt to investigate the connection between siderophore biosynthesis and FOB utilization, experiments were conducted to demonstrate the repression of sidA when P. brasiliensis was incubated with FOB. In addition, SidA accumulation, at both transcriptional and proteomic level, and the cognate enzymatic activity were reduced in cells cultured in the presence of FOB, when compared to cells growing
A

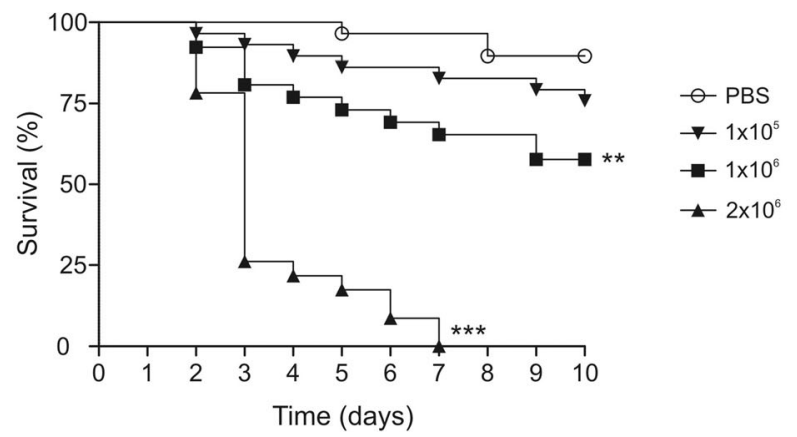

B

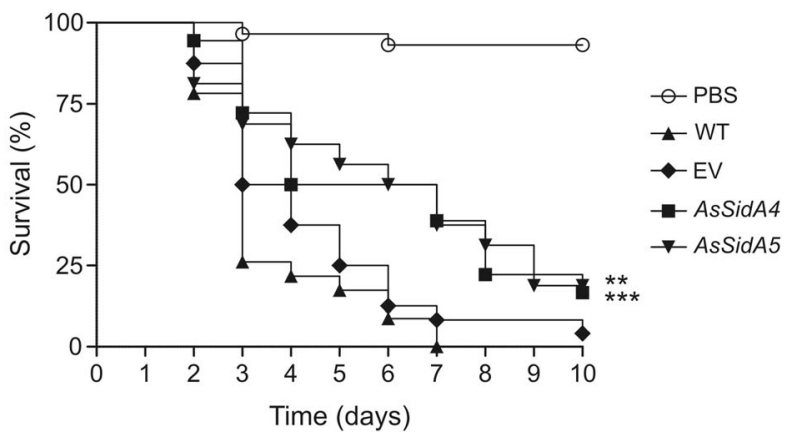

Fig. 6 Survival curves of T. molitor infected with $P$. brasiliensis yeast strains. T. molitor larvae were infected with different concentrations of $P$. brasiliensis yeast cells of WT strain (a) and with $2 \times 10^{6}$ yeast cells of the WT, EV and AsSidA mutant strains (AsSidA4 and AsSidA5) (b). As a control, the larvae were inoculated with PBS only. The experiments were carried with a total of 30 larvae for each condition analyzed in a period of 10 days. The survival of $T$. molitor larvae is shown as a percentage. ( ${ }^{* *} p<0.0005,{ }^{* *} p<0.005$ and ${ }^{*} p<0.05$ ) 
in iron depleted medium. Similar results employing xenosiderophores were described for Candida albicans, Saccharomyces cerevisiae and A. nidulans (Heymann et al. 2002; Haas 2003; Philpott and Protchenko 2008).

In order to better explore the impact of FOB over $P$. brasiliensis growth a proteomic analysis was performed. Data allowed the identification of several proteins involved in siderophores biosynthesis. Notably, the decrease of SidA levels in presence of FOB was the most glaring result. Thus, all the data obtained in this study demonstrate that, in the presence of FOB, SidA is repressed both transcriptionally and translationally, and evidences the siderophore biosynthesis pathway in $P$. brasiliensis.

To confirm the function of SidA in the production of siderophores and the role of this protein in the biology of $P$. brasiliensis, we silenced the sidA gene by using antisense RNA technique. The same system was already reported to obtain $P$. brasiliensis silenced clones for proteins playing relevant roles in the fungal pathobiology, e.g., Cdc42p (Almeida et al. 2009), PbHAD32 (Hernandez et al. 2010), PbRbt5 (Bailao et al. 2014), Pbccp (Parente-Rocha et al. 2015), Pb14-3-3 (Marcos et al. 2016), and PbPCN (Fernandes et al. 2017). Here we have successfully obtained knockdown strains for PbsidA, as demonstrated by qRT-PCR.

As silencing of sidA gene did not impair fungal growth in regular culture media, the phenotypic characterization of this gene was performed employing iron deprivation conditions. The qualitative O-CAS assay showed that production of siderophores in the knockdown strains was diminished when compared to the WT and EV strains. Furthermore, a semi-quantitative CAS liquid assay also highlighted the diminished production of siderophores with and without iron.

Although murine models are valuable tools for in vivo infection studies, invertebrate models are becoming prominent alternatives. The ethical reasons linked to vertebrate models, as well as the high costs for animal management have propelled the examination of viable substitutes (Wilson-Sanders 2011). Several studies have demonstrated the use of Galleria mellonella larvae to characterize the infection process in pathogenic fungi, such as Histoplasma capsulatum, C. albicans, Cryptococcus neoformans and P. brasiliensis (Thomaz et al. 2013; Vargas et al. 2015; Bouklas et al. 2015; Scorzoni et al. 2015; Marcos et al. 2019). However, G. mellonella is an animal that requires almost daily handling, as well as these insects are not sold worldwide (Jorjao et al. 2018). An alternative that has been explored are larvae of T. molitor, an animal that is easy to handle, is marketed by several suppliers and is a low cost insect. Furthermore, the T. molitor larvae have been standardized as an in vivo infection model for several fungal pathogens as C. albicans, C. neoformans, Malassezia furfur and Fonsecaea pedrosoi (de Souza et al. 2015; Silva et al. 2018; Fornari et al. 2018). Here, we explored the application of T. molitor as an invertebrate infection model for $P$. brasiliensis. Noteworthy, increasing the viable cell concentration in the inoculum also increases $T$. molitor larvae mortality. The same observations can be draw for C. albicans and C. neoformans, demonstrating that this model is efficient for assessing the virulence of pathogenic fungi (de Souza et al. 2015).

Metal restriction is one of the several mechanisms employed by host cells to inhibit microbial development (Ganz 2016; Ganz 2018; Brechting and Rappleye 2019). Thus, the presence of a high affinity iron acquisition systems appears to be an essential strategy to circumvent the absence of this metal during growth in a hostile environment (McDonagh et al. 2008; Hilty et al. 2011; Pasricha et al. 2016; Kalidasan et al. 2018). In several fungal pathogens, siderophores are important for virulence and hostpathogen interaction (Heymann et al. 2002; Schrettl et al. 2004; Schrettl et al. 2010; Nevitt and Thiele 2011). For example, in $H$. capsulatum, the deletion of sid1, the homologue of sidA of A. fumigatus, promoted decreasing of siderophore production, resulting in diminished proliferation inside macrophages and murine pulmonary colonization (Hwang et al. 2008). Similarly, previous results pointed for a putative role of these molecules in pathogenesis of $P$. brasiliensis, since the expression of sidA was highly induced during fungal infection to macrophages (Silva-Bailao et al. 2014). The bioassays conducted here with AsSidA mutants support a main role of siderophores in the infection process of Paracoccidioides species. AsSidA mutants presented reduced virulence to $T$. molitor larvae, reasserting the importance of iron for host colonization.

\section{CONCLUSIONS}

Although previous results pointed that $P$. brasiliensis harbors a complete pathway for siderophore production several aspects about SidA regulation and activity were still to be determined. The molecular modelling, here employed, helped to highlight structural similarities between A. fumigatus SidA and P. brasiliensis SidA. Furthermore, the expression of SidA is repressed, at transcriptional and translational levels, in the presence of a xenosiderophore FOB. Moreover, sidA silencing in blocks the production of siderophores and promotes decrease in fungal virulence $P$. brasiliensis. Due to the relevance of iron for fungal survival inside the host, strategies aiming to block siderophore biosynthesis can be successful, helping to eliminate the infection. In this way, future studies will focus on molecules capable to block SidA activity.

\section{Supplementary information}

Supplementary information accompanies this paper at https://doi.org/10. 1186/s43008-020-00035-X.

Additional file 1: Figure S1. Molecular structure of L-ornithine- $\mathrm{N}^{5}$ monooxygenase. (A) AfSidA from Aspergillus fumigatus PDBID: 4B63 (gray) 
and PbSidA (blue) alignment using the Pymol viewer, evidencing the interactions among L-ornithine, FAD and NADPH. (B) Amino acid residues of $P$. brasiliensis SidA described as mainly involved in the interaction with $L$-ornithine and $(C)$ cofactors are essential for the maintenance of them in the active site.

Additional file 2: Figure S2. Molecular dynamics of $P$. brasiliensis SidA. (A) Cluster and (B) RMSD graphs. It is observed that the stability starts at approximately $20 \mathrm{~ns}$ and that the most representative conformational mode of the trajectory is cluster 1. (C) Ramachandran diagrams of the three-dimensional model of SidA before molecular dynamics and (D) after molecular dynamics. (E) RMSF graph showing the more flexible residues (red) along the molecular dynamics. (F) Three-dimensional structure of SidA showing the most flexible regions (red) and pockets of the active site (green and orange).

Additional file 3: Figure S3. Characterization of the recombinant protein. MS/MS spectrum of the recombinant protein SidA identified by mass spectrometry.

Additional file 4: Table S1. Oligonucleotides used in this study. Additional file 5: Table S2. Analysis of the quality of the SidA models through the Molprobity server.

Additional file 6: Table S3.

\section{Acknowledgements}

We thank the CAPES, CNPq and FAPEG for providing fellowships to MG Silva JS de Curcio, MV Tomazett, AF Souza, VRMC Leite and RM Lima. We also thank Dr. Augusto Schrank for the helpful suggestions.

\section{Adherence to national and international regulations}

Not applicable.

\section{Authors' contributions}

CMA Soares and MG Silva conceived and designed the experiments. MG Silva, JS de Curcio, MV Tomazett, AF Souza, VRMC Leite, RM Lima, N Sbaraini and RA Gonçales performed the experiments. MG Silva, JS de Curcio, MGS Bailão, AM Bailão, and CMA Soares analyzed and/or interpreted the data. M Pereira, F Rodrigues and CMA Soares contributed with reagents and materials. MG Silva, JS de Curcio, MGS Bailão and CMA Soares wrote the manuscript. The authors read and approved the final manuscript.

\section{Funding}

CMAS and MP are fellows from Conselho Nacional de Desenvolvimento Científico e Tecnológico (CNPq). MT and VRMCL is a fellow from Fundação de Amparo à Pesquisa do Estado de Goiás (FAPEG). RAG was supported by Coordenação de Aperfeiçoamento de Pessoal de Nível Superior (CAPES; grant: 88887.333726/2019-00). FR was supported by the Northern Portugal Regional Operational Programme (NORTE 2020), under the Portugal 2020 Partnership Agreement, through the European Regional Development Fund (FEDER) (NORTE-01-0145-FEDER-000013). This work was supported by grants from Conselho Nacional de Desenvolvimento Científico e Tecnológico (CNPq) and Fundação de Amparo à Pesquisa do Estado de Goiás (FAPEG)Instituto Nacional de Ciência e Tecnologia (INCT) de Estratégias de Interação Patógeno-Hospedeiro.

\section{Availability of data and materials}

Not applicable.

\section{Ethics approval and consent to participate}

All the animal work carried out in accordance with the ethical principles of animal research adopted by the Brazilian Society of Laboratory Animal Science and a Brazilian Federal Law 11.749 (October 2008).

\section{Consent for publication}

Not applicable.

\section{Competing interests}

The authors declare that they have no competing interests.

\section{Author details}

'Laboratório de Biologia Molecular, Instituto de Ciências Biológicas, ICB II, Campus II, Universidade Federal de Goiás, Goiânia, GO, Brazil. ²Programa de Pós-graduação em Patologia Molecular, Faculdade de Medicina, Universidade de Brasília, Brasília, DF 70910-900, Brazil. ${ }^{3}$ Centro de Biotecnologia, Programa de Pós-graduação em Biologia Celular e Molecular, Universidade Federal do Rio Grande do Sul, Porto Alegre, RS, Brazil. ${ }^{4}$ Life and Health Sciences Research Institute (ICVS), School of Medicine, University of Minho, Braga, Portugal. ${ }^{5}$ ICVS/3B's - PT Government Associate Laboratory, Braga/Guimarães, Portugal.

Received: 30 January 2020 Accepted: 11 June 2020

Published online: 29 June 2020

\section{References}

Almeida AJ, Carmona JA, Cunha C, Carvalho A, Rappleye CA, Goldman WE et al (2007) Towards a molecular genetic system for the pathogenic fungus Paracoccidioides brasiliensis. Fungal Genet Biol 44(12):1387-1398

Almeida AJ, Cunha C, Carmona JA, Sampaio-Marques B, Carvalho A, Malavazi I et al (2009) Cdc42p controls yeast-cell shape and virulence of Paracoccidioides brasiliensis. Fungal Genet Biol 46(12):919-926

Baeza LC, da Mata FR, Pigosso LL, Pereira M, de Souza G, Coelho ASG et al (2017) Differential metabolism of a two-carbon substrate by members of the Paracoccidioides genus. Front Microbiol 8:2308

Bailao EF, de Lima PS, Silva-Bailao MG, Bailao AM, Fernandes Gda R, Kosman DJ et al (2015) Paracoccidioides spp. ferrous and ferric iron assimilation pathways. Front Microbiol 6:821

Bailao EF, Parente JA, Pigosso LL, Castro KP, Fonseca FL, Silva-Bailao MG et al (2014) Hemoglobin uptake by Paracoccidioides spp. is receptor-mediated. PLoS Negl Trop Dis 8(5):e2856

Bailão EFLC, Parente AFA, Parente JA, Silva-Bailão MGS, Castro KP, Kmetzsch L et al (2012) Metal acquisition and homeostasis in fungi. Curr Fungal Infect Rep 6:257-266

Blatzer M, Schrettl M, Sarg B, Lindner HH, Pfaller K, Haas H (2011) SidL, an Aspergillus fumigatus transacetylase involved in biosynthesis of the siderophores ferricrocin and hydroxyferricrocin. Appl Environ Microbiol 77(14):4959-4966

Bookout AL, Cummins CL, Mangelsdorf DJ, Pesola JM, Kramer MF (2006) Highthroughput real-time quantitative reverse transcription PCR. Curr Protoc Mol Biol Chapter 15(15.8):1-28

Bouklas T, Diago-Navarro E, Wang X, Fenster M, Fries BC (2015) Characterization of the virulence of Cryptococcus neoformans strains in an insect model. Virulence 6(8):809-813

Bradford MM (1976) A rapid and sensitive method for the quantitation of microgram quantities of protein utilizing the principle of protein-dye binding. Anal Biochem 72:248-254

Brechting PJ, Rappleye CA (2019) Histoplasma responses to nutritional immunity imposed by macrophage activation. J Fungi (Basel) 5(2):45

Canessa P, Larrondo LF (2013) Environmental responses and the control of iron homeostasis in fungal systems. Appl Microbiol Biotechnol 97(3):939-955

Chen VB, Arendall WB 3rd, Headd JJ, Keedy DA, Immormino RM, Kapral GJ et al (2010) MolProbity: all-atom structure validation for macromolecular crystallography. Acta Crystallogr D Biol Crystallogr 66(Pt 1):12-21

Chocklett SW, Sobrado P (2010) Aspergillus fumigatus SidA is a highly specific ornithine hydroxylase with bound flavin cofactor. Biochemistry 49(31):67776783

Cox CD (1994) Deferration of laboratory media and assays for ferric and ferrous ions. Methods Enzymol 235:315-329

de Souza P, Custodio Caloni C, Wilson D, Sergio Almeida R (2018) An invertebrate host to study fungal infections, mycotoxins and antifungal drugs: Tenebrio molitor. J Fungi (Basel) 4(4):125

de Souza PC, Morey AT, Castanheira GM, Bocate KP, Panagio LA, Ito FA et al (2015) Tenebrio molitor (Coleoptera: Tenebrionidae) as an alternative host to study fungal infections. J Microbiol Methods 118:182-186

Fernandes FF, Oliveira AF, Landgraf TN, Cunha C, Carvalho A, Vendruscolo PE et al (2017) Impact of Paracoccin gene silencing on Paracoccidioides brasiliensis virulence. MBio 8(4):e00537-e00517

Fornari G, Gomes RR, Degenhardt-Goldbach J, Dos Santos SS, de Almeida SR, Dos Santos GD et al (2018) A model for trans-kingdom pathogenicity in Fonsecaea agents of human Chromoblastomycosis. Front Microbiol 9:2211 
Franceschini S, Fedkenheuer M, Vogelaar NJ, Robinson HH, Sobrado P, Mattevi A (2012) Structural insight into the mechanism of oxygen activation and substrate selectivity of flavin-dependent $\mathrm{N}$-hydroxylating monooxygenases. Biochemistry 51(36):7043-7045

Ganz T (2009) Iron in innate immunity: starve the invaders. Curr Opin Immunol 21(1):63-67

Ganz T (2016) Macrophages and iron metabolism. Microbiol Spectr 4(5):1-10

Ganz T (2018) Iron and infection. Int J Hematol 107(1):7-15

Geromanos SJ, Vissers JP, Silva JC, Dorschel CA, Li GZ, Gorenstein MV et al (2009) The detection, correlation, and comparison of peptide precursor and product ions from data independent LC-MS with data dependant LC-MS/MS. Proteomics 9(6):1683-1695

Haas H (2003) Molecular genetics of fungal siderophore biosynthesis and uptake: the role of siderophores in iron uptake and storage. Appl Microbiol Biotechnol 62(4):316-330

Haas H, Schoeser M, Lesuisse E, Ernst JF, Parson W, Abt B et al (2003) Characterization of the Aspergillus nidulans transporters for the siderophores enterobactin and triacetylfusarinine C. Biochem J 371(Pt 2):505-513

Haas H, Zadra I, Stoffler G, Angermayr K (1999) The Aspergillus nidulans GATA factor SREA is involved in regulation of siderophore biosynthesis and control of iron uptake. J Biol Chem 274(8):4613-4619

Haber F, Weiss J (1934) The catalytic decomposition of hydrogen peroxide by iron salts. Proc Royal Soc London 147:332-351

Halliwell B, Gutteridge JM (1984) Oxygen toxicity, oxygen radicals, transition metals and disease. Biochem J 219(1):1-14

Hernandez O, Almeida AJ, Gonzalez A, Garcia AM, Tamayo D, Cano LE et al (2010) A 32-kilodalton hydrolase plays an important role in Paracoccidioides brasiliensis adherence to host cells and influences pathogenicity. Infect Immun 78(12):5280-5286

Heymann P, Gerads M, Schaller M, Dromer F, Winkelmann G, Ernst JF (2002) The siderophore iron transporter of Candida albicans (Sit1p/Arn1p) mediates uptake of ferrichrome-type siderophores and is required for epithelial invasion. Infect Immun 70(9):5246-5255

Hilty J, George Smulian A, Newman SL (2011) Histoplasma capsulatum utilizes siderophores for intracellular iron acquisition in macrophages. Med Mycol 49(6):633-642

Hwang LH, Mayfield JA, Rine J, Sil A (2008) Histoplasma requires SID1, a member of an iron-regulated siderophore gene cluster, for host colonization. PLoS Pathog 4(4):e1000044

Jorjao AL, Oliveira LD, Scorzoni L, Figueiredo-Godoi LMA, Cristina APM, Jorge AOC et al (2018) From moths to caterpillars: ideal conditions for Galleria mellonella rearing for in vivo microbiological studies. Virulence 9(1):383-389

Kalidasan V, Azman A, Joseph N, Kumar S, Awang Hamat R, Neela VK (2018) Putative iron Acquisition Systems in Stenotrophomonas maltophilia. Molecules 23(8):2048

Kornitzer D (2009) Fungal mechanisms for host iron acquisition. Curr Opin Microbiol 12(4):377-383

Kosman DJ (2003) Molecular mechanisms of iron uptake in fungi. Mol Microbiol 47(5):1185-1197

Krithika R, Marathe U, Saxena P, Ansari MZ, Mohanty D, Gokhale RS (2006) A genetic locus required for iron acquisition in Mycobacterium tuberculosis. Proc Natl Acad Sci U S A 103(7):2069-2074

Lima Pde S, Chung D, Bailao AM, Cramer RA, Soares CM (2015) Characterization of the Paracoccidioides hypoxia response reveals new insights into pathogenesis mechanisms of this important human pathogenic fungus. PLoS Negl Trop Dis 9(12):e0004282

Machuca A, Milagres AM (2003) Use of CAS-agar plate modified to study the effect of different variables on the siderophore production by Aspergillus. Lett Appl Microbiol 36(3):177-181

Marcos CM, de Silva JF, Oliveira HC, Assato PA, Singulani Jde L, Lopez AM et al (2016) Decreased expression of 14-3-3 in Paracoccidioides brasiliensis confirms its involvement in fungal pathogenesis. Virulence 7(2):72-84

Marcos CM, Tamer G, de Oliveira HC, Assato PA, Scorzoni L, Santos CT et al (2019) Down-regulation of TUFM impairs host cell interaction and virulence by Paracoccidioides brasiliensis. Sci Rep 9(1):17206

McDonagh A, Fedorova ND, Crabtree J, Yu Y, Kim S, Chen D et al (2008) Subtelomere directed gene expression during initiation of invasive aspergillosis. PLoS Pathog 4(9):e1000154

McEwen JG, Bedoya V, Patino MM, Salazar ME, Restrepo A (1987) Experimental murine paracoccidiodomycosis induced by the inhalation of conidia. J Med Vet Mycol 25(3):165-175
Menino JF, Almeida AJ, Rodrigues F (2012) Gene knockdown in Paracoccidioides brasiliensis using antisense RNA. Methods Mol Biol 845:187-198

Murad AM, Souza GH, Garcia JS, Rech EL (2011) Detection and expression analysis of recombinant proteins in plant-derived complex mixtures using nanoUPLCMS(E). J Sep Sci 34(19):2618-2630

Neilands JB (1993) Siderophores. Arch Biochem Biophys 302(1):1-3

Nevitt T, Thiele DJ (2011) Host iron withholding demands siderophore utilization for Candida glabrata to survive macrophage killing. PLoS Pathog 7(3): e1001322

Nogueira SV, Fonseca FL, Rodrigues ML, Mundodi V, Abi-Chacra EA, Winters MS et al (2010) Paracoccidioides brasiliensis enolase is a surface protein that binds plasminogen and mediates interaction of yeast forms with host cells. Infect Immun 78(9):4040-4050

Parente AF, Bailao AM, Borges CL, Parente JA, Magalhaes AD, Ricart CA et al (2011) Proteomic analysis reveals that iron availability alters the metabolic status of the pathogenic fungus Paracoccidioides brasiliensis. PLoS One 6(7): e22810

Parente-Rocha JA, Parente AF, Baeza LC, Bonfim SM, Hernandez O, McEwen JG et al (2015) Macrophage interaction with Paracoccidioides brasiliensis yeast cells modulates fungal metabolism and generates a response to oxidative stress. PLoS One 10(9):e0137619

Pasricha S, Schafferer L, Lindner H, Joanne Boyce K, Haas H, Andrianopoulos A (2016) Differentially regulated high-affinity iron assimilation systems support growth of the various cell types in the dimorphic pathogen Talaromyces marneffei. Mol Microbiol 102(4):715-737

Perez-Miranda S, Cabirol N, George-Tellez R, Zamudio-Rivera LS, Fernandez FJ (2007) O-CAS, a fast and universal method for siderophore detection. J Microbiol Methods 70(1):127-131

Philpott CC, Protchenko O (2008) Response to iron deprivation in Saccharomyces cerevisiae. Eukaryot Cell 7(1):20-27

Pronk S, Pall S, Schulz R, Larsson P, Bjelkmar P, Apostolov R et al (2013) GROMACS 4.5: a high-throughput and highly parallel open source molecular simulation toolkit. Bioinformatics 29(7):845-854

Raymond KN, Dertz EA, Kim SS (2003) Enterobactin: an archetype for microbial iron transport. Proc Natl Acad Sci U S A 100(7):3584-3588

Restrepo A (1985) The ecology of Paracoccidioides brasiliensis: a puzzle still unsolved. Sabouraudia 23(5):323-334

Restrepo A, Jimenez BE (1980) Growth of Paracoccidioides brasiliensis yeast phase in a chemically defined culture medium. J Clin Microbiol 12(2):279-281

Restrepo A, McEwen JG, Castaneda E (2001) The habitat of Paracoccidioides brasiliensis: how far from solving the riddle? Med Mycol 39(3):233-241

Rezende TC, Borges CL, Magalhaes AD, de Sousa MV, Ricart CA, Bailao AM et al (2011) A quantitative view of the morphological phases of Paracoccidioides brasiliensis using proteomics. J Proteomics 75(2):572-587

Rigsby RE, Parker AB (2016) Using the PyMOL application to reinforce visual understanding of protein structure. Biochem Mol Biol Educ 44(5):433-437

Robinson R, Franceschini S, Fedkenheuer M, Rodriguez PJ, Ellerbrock J, Romero E et al (2014) Arg279 is the key regulator of coenzyme selectivity in the flavindependent ornithine monooxygenase SidA. Biochim Biophys Acta 1844(4): 778-784

Robinson R, Qureshi IA, Klancher CA, Rodriguez PJ, Tanner JJ, Sobrado P (2015) Contribution to catalysis of ornithine binding residues in ornithine N5monooxygenase. Arch Biochem Biophys 585:25-31

San-Blas G, Nino-Vega G, Iturriaga T (2002) Paracoccidioides brasiliensis and paracoccidioidomycosis: molecular approaches to morphogenesis, diagnosis, epidemiology, taxonomy and genetics. Med Mycol 40(3):225-242

Sanchez M, Sabio L, Galvez N, Capdevila M, Dominguez-Vera JM (2017) Iron chemistry at the service of life. IUBMB Life 69(6):382-388

Schneider CA, Rasband WS, Eliceiri KW (2012) NIH image to ImageJ: 25 years of image analysis. Nat Methods 9(7):671-675

Schrettl M, Bignell E, Kragl C, Joechl C, Rogers T, Arst HN Jr et al (2004) Siderophore biosynthesis but not reductive iron assimilation is essential for Aspergillus fumigatus virulence. J Exp Med 200(9):1213-1219

Schrettl M, Bignell E, Kragl C, Sabiha Y, Loss O, Eisendle M et al (2007) Distinct roles for intra- and extracellular siderophores during Aspergillus fumigatus infection. PLoS Pathog 3(9):1195-1207

Schrettl M, Ibrahim-Granet O, Droin S, Huerre M, Latge JP, Haas H (2010) The crucial role of the Aspergillus fumigatus siderophore system in interaction with alveolar macrophages. Microbes Infect 12(12-13):1035-1041

Schwyn B, Neilands JB (1987) Universal chemical assay for the detection and determination of siderophores. Anal Biochem 160(1):47-56 
Scorzoni L, de Paula e Silva AC, de Singulani JL, Leite FS, de Oliveira HC, da Silva RA et al (2015) Comparison of virulence between Paracoccidioides brasiliensis and Paracoccidioides lutzii using Galleria mellonella as a host model. Virulence 6(8):766-776

Silva APRV, A. D, Viana RO, Ricoy A, C. DS, Johann S, Alves VDS (2018) Caenorhabditis elegans and Tenebrio molitor - new tools to investigate Malassezia species Preprints 1

Silva MG, Schrank A, Bailao EF, Bailao AM, Borges CL, Staats CC et al (2011) The homeostasis of iron, copper, and zinc in Paracoccidioides brasiliensis, Cryptococcus neoformans var. grubii, and Cryptococcus gattii: a comparative analysis. Front Microbiol 2:49

Silva-Bailao MG, Bailao EF, Lechner BE, Gauthier GM, Lindner H, Bailao AM et al (2014) Hydroxamate production as a high affinity iron acquisition mechanism in Paracoccidioides spp. PLoS One 9(8):e105805

Thomaz L, Garcia-Rodas R, Guimaraes AJ, Taborda CP, Zaragoza O, Nosanchuk JD (2013) Galleria mellonella as a model host to study Paracoccidioides lutzii and Histoplasma capsulatum. Virulence 4(2):139-146

Tomazett MV, Baeza LC, Paccez JD, Parente-Rocha JA, Ribeiro-Dias F, Soares CMA (2019) Identification and characterization of Paracoccidioides /utzii proteins interacting with macrophages. Microbes Infect S1286-4579(19):3004630042[pii]. https://doi.org/10.1016/j.micinf.2019.03.002

Vargas G, Rocha JD, Oliveira DL, Albuquerque PC, Frases S, Santos SS et al (2015) Compositional and immunobiological analyses of extracellular vesicles released by Candida albicans. Cell Microbiol 17(3):389-407

Wilson-Sanders SE (2011) Invertebrate models for biomedical research, testing, and education. ILAR J 52(2):126-152

Yang J, Zhang Y (2015) Protein structure and function prediction using I-TASSER. Curr Protoc Bioinformatics 52:581-515

Zambuzzi-Carvalho PF, Tomazett PK, Santos SC, Ferri PH, Borges CL, Martins WS et al (2013) Transcriptional profile of Paracoccidioides induced by oenothein $B$, a potential antifungal agent from the Brazilian Cerrado plant Eugenia uniflora. BMC Microbiol 13:227

Zhou LW, Haas H, Marzluf GA (1998) Isolation and characterization of a new gene, sre, which encodes a GATA-type regulatory protein that controls iron transport in Neurospora crassa. Mol Gen Genet 259(5):532-540

\section{Publisher's Note}

Springer Nature remains neutral with regard to jurisdictional claims in published maps and institutional affiliations.

Ready to submit your research? Choose BMC and benefit from:

- fast, convenient online submission

- thorough peer review by experienced researchers in your field

- rapid publication on acceptance

- support for research data, including large and complex data types

- gold Open Access which fosters wider collaboration and increased citations

- maximum visibility for your research: over $100 \mathrm{M}$ website views per year

At $\mathrm{BMC}$, research is always in progress.

Learn more biomedcentral.com/submissions 